\title{
GTF3C6 Gene
}

National Cancer Institute

\section{Source}

National Cancer Institute. GTF3C6 Gene. NCI Thesaurus. Code C89716.

This gene plays a role in RNA polymerase III-mediated transcription. 